\title{
Microbial biofilms and mitigation of loss of agro-biodiversity in degraded soils
}

\author{
Lasantha Herath, Gamini Seneviratne*, J.A. Wethma Wishwajee Jayasinghe and D.M. Nirmala \\ Senanayake \\ Microbial Biotechnology Unit, National Institute of Fundamental Studies, Hantana Road, Kandy.
}

Revised: 30 January 2017; Accepted: 16 March 2017

\begin{abstract}
Modern agriculture has been one of the causes for biodiversity degradation. Conservation of the remaining biodiversity is of utmost importance and novel approaches and concepts should be tested to achieve this end. As a recent development in microbiology, fungal surface-attached bacterial communities or fungal-bacterial biofilms (FBBs) are being studied for various biotechnological applications with consequences in ecosystem functioning and biodiversity. The present study was conducted to investigate the effect of the introduced FBBs on restoration of reduced biodiversity in the soil of a degraded tea land. The soil was treated with a developed biofilm, its monocultures, the nutrient solution used for culturing the microbes, and sterilised distilled water in a pot experiment. After three months, the soils were evaluated for plant and culturable microbial species richness, microfaunal count, nitrogenase activity, and selected soil parameters. It was observed that the biofilm application resulted in a significantly higher plant species richness than the respective monocultures $(\mathrm{p}<0.05)$. Further, culturable bacterial and fungal species richnesses, soil nitrogenase activity, organic carbon, and available ammonium and nitrate increased significantly with the biofilm application, compared with the application of the nutrient solution and distilled water $(p<0.05)$. Results of the present study indicated that inoculation of the developed microbial biofilms influences microbial and plant diversity and soil quality parameters positively. These observations indicate that the microbial biofilms developed in this study may have the potential to be developed as a novel biotechnological tool to mitigate biodiversity loss in agroecosystems and perhaps in natural ecosystems.
\end{abstract}

Keywords: Agroecosystems, biodiversity, conservation, fungal-bacterial biofilms.

\section{INTRODUCTION}

Biodiversity is the variability amongst living organisms, including diversity within species, between species and of ecosystems (Macel et al., 2010). It is important for the functioning of all ecosystems. Excessive loss of biodiversity may impose real costs on resource users (Watson et al., 1996), and also lead to species extinction. Modern agriculture is one of the greatest extinction threats to biodiversity in most of the agroecosystems (Jackson et al., 2005). Biodiversity loss in agricultural landscapes affects not only the production of food, fuel and fibre, but also a range of ecological services, resulting in gradual decline in crop productivity. Thus, the conservation of remaining biodiversity has been given a top priority at present (Phalan et al., 2011). Most common tools of in situ and ex situ conservation of agro-biodiversity such as land sharing and land sparing, respectively have been reported to be insufficient to halt biodiversity loss and decline especially in agroecosystems (Kleijn et al., 2011).

Plant-microbe interactions in the soil mediate key processes that control ecosystems, and they potentially represent a mechanistic link between plant diversity and ecosystem function (Zak et al., 2003). Further, Wittebolle et al. (2009) have reported that functional stability of ecosystems is strongly influenced by diverse microbial communities in the soil. Haphazard use of chemical inputs in agroecosystems results in collapse of microbial

*Corresponding author (gaminis@ifs.ac.lk; (iD https://orcid.org/0000-0003-1562-4097) 
communities, particularly $\mathrm{N}_{2}$ fixers, which will lead to a reduction in microbial diversity (van der Heijden et al., 2006; Hadgu et al., 2009). Hence, restoring the degraded microbial community structure is crucial for the sustainability of agroecosystems.

As a recent development in microbiology, surfaceattached microbial communities or biofilms are being studied for various biotechnological applications. In this field of research, bacteria in the fungal surface-attached biofilm mode [fungal-bacterial biofilms (FBBs)] can be developed in vitro from microbial monocultures (Seneviratne et al., 2008). When the FBBs were applied to agricultural ecosystems, increased nitrogen fixation, mineral nutrient release in the soil, organic acid and plant growth hormone production, enhanced plant growth, yield and environmental stress tolerance were observed, compared to mono or mixed cultures of the component microbes without biofilm formation (Seneviratne et al., $2008 ; 2011)$. These processes are very important for improved ecosystem functioning. However, studies on the relationship between the above processes and biodiversity when FBBs are used have not been done adequately. Thus, the present study was conducted to evaluate the effect of the developed microbial biofilms on agro-biodiversity.

\section{METHODOLOGY}

\section{Preparation of soil samples}

Soil samples were collected from a degraded tea plantation in Hantana, Sri Lanka [mid country Wet Zone (WM3) $510 \mathrm{~m}$ amsl, mean annual temperature $25.5^{\circ} \mathrm{C}$ ]. Soil type at the site was red yellow podzolic with a texture of clay loam, $\mathrm{pH} 4.1,1.05 \% \mathrm{C}$ and $0.04 \% \mathrm{~N}$. The top litter and the organic layer up to a $5 \mathrm{~cm}$ depth was removed and soil samples were collected up to $25 \mathrm{~cm}$ depth from 5 random locations. Samples were then mixed thoroughly to form one homogenised sample and sieved $(<2 \mathrm{~mm})$ to remove organic debris and gravel.

\section{Development of FBBs}

To develop a FBB in vitro, Acetobacter spp., Azotobacter spp., Rhizobium spp., Bradyrhizobium spp. and nonpathogenic Colletotrichum spp. were co-cultured in modified yeast mannitol broth according to the protocols by Seneviratne et al. (2011). All microbial cultures were obtained from the culture collection of the Microbial Biotechnology Unit, National Institute of Fundamental Studies, Hantana Road, Kandy, Sri Lanka. The above bacterial species were selected based on the biofilm formation ability (microscopic observation), and nitrogenase activity [acetylene reduction assay (ARA), Zuberer \& Silver, 1978] in co-culturing at screening.

\section{Application of the treatments and analysis of soil}

The developed FBB was diluted 16 times with sterilised distilled water to give $10^{6} \mathrm{CFU}$ of bacterial cells $/ \mathrm{mL}$. Plastic pots (diameter $15 \mathrm{~cm}$, height $5 \mathrm{~cm}$ ) were filled with $800 \mathrm{~g}$ of the prepared soil. The pots were treated separately with;

(i) $10 \mathrm{~mL}$ solution of diluted FBB,

(ii) $10 \mathrm{~mL}$ nutrient solution used to culture the FBB [i.e. nutrient broth (Himedia ${ }^{\mathrm{TM}}$, India) $13 \mathrm{~g} / \mathrm{L}$ of medium],

(iii) $10 \mathrm{~mL}$ sterilised distilled water and,

(iv) $10 \mathrm{~mL}$ each of monocultures of microbes, which contributed to form the FBB (with the same cell density and dilution as above).

All treatments were triplicated, and the pots were arranged in a completely randomised design in a greenhouse (temperature range $27-33{ }^{\circ} \mathrm{C}$ ). The pots were watered with sterile distilled water and maintained for 3 months.

The different plant species and their numbers that grew in the plastic pots were counted after 3 months and their families were identified using morphological features. The study investigated the effect of the introduced biofilms on the variety and variability of plants without identifying the plants to genus or species level. Plants were then removed from the pots and the soil was subjected to chemical and microbiological analysis. The soil was first slightly air-dried and sieved $(<2 \mathrm{~mm})$ to remove organic debris. This was followed by a series of dilutions before spread plating on nutrient agar [NA, (Himedia ${ }^{\mathrm{TM}}$, India) $21 \mathrm{~g} / \mathrm{L}$ of medium] plates to estimate culturable bacterial counts. The plates were incubated at $30{ }^{\circ} \mathrm{C}$ for $24 \mathrm{~h}$. Emerged colonies were counted and the mean number of colonies of 3 plates was evaluated. The same procedure was used to estimate culturable diazotrophic richness in the soil using combined carbon medium (CCM) (Koomnok et al., 2007), followed by the assessment of nitrogenase activity using ARA (Zuberer \& Silver, 1978). Fungal species richness was evaluated using the potato dextrose agar ( $39 \mathrm{~g} / \mathrm{L}$ PDA, Himedia ${ }^{\mathrm{TM}}$, India) medium. Counts of unicellular and multicellular microfauna were made under the light microscope (Olympus, Japan) using a Neubauer haemocytometer. Estimations were done according to the most probable number (MPN) technique described by Coleman et al. (1999). Subsamples of the sieved soil were used to determine available $\mathrm{NO}_{3}^{-}$(Cataldo et al., 1975), $\mathrm{NH}_{4}^{+}$ 
(Anderson \& Ingram, 1993), and also the nitrogenase activity using ARA. The rest of the sample was airdried, sieved $(<2 \mathrm{~mm})$ and used for analysing organic $\mathrm{C}$ by wet oxidation method followed by colourimetric determination using UV-vis spectrophotometer (Anderson \& Ingram, 1993).

\section{Data analysis}

Statistical analyses of data were conducted using one way-ANOVA after normality and residual tests, and the means were separated by LSD test at $5 \%$ probability level. All data were analysed using SAS (1998) software.

\section{RESULTS AND DISCUSSION}

The biofilm treated soil pots harboured a significantly higher plant species richness than monoculture treatments ( $\mathrm{p}<0.05$; Figure 1a). It is reported that such effects may be attributed to improved ecosystem functionality rendered by microbial communities, and also subsequent mutual effects between the microbes and the plant root (Goenadi \& Santi, 2009; Nadrowski et al., 2010 ). This increased plant emergence has been recently explained to be caused by breaking the dormancy of plant seed bank in the soil due to biofilm action (Seneviratne, 2012). Soil microbial communities have been reported to play a similar important role in determining plant species diversity even in natural ecosystems such as forests (Mangan et al., 2010). It has been demonstrated that the cumulative beneficial effects of microbial biofilms are higher than that of their monocultures (Seneviratne et al., 2008; Swarnalakshmi et al., 2013). When the soil in biofilm applied pots were compared with the soil in the pots to which nutrient solution and sterilised distilled water were added, it was observed that the biofilm facilitated the highest plant species richness followed by the nutrient solution (Figure 1b). The soil pots to which sterilised distilled water was added showed a lower species richness than that of the biofilm treated pots. In the natural soil environment among many other factors, microbial growth is suppressed by inadequate nutrient supply. Thus, nutrient supplementation boosts microbial growth and hence plant growth. The main plant families that emerged in this study were found to be Fabaceae, Poaceae, Labiatae and Cyperaceae. These families were present in all the treatments, but with a higher number of species in the biofilm applied pots.

The soil in the biofilm treated pots showed a significantly high nitrogenase activity and a higher number of diazotrophic bacteria, compared to the pots treated with nutrient solution and sterilised distilled water
( $p<0.05$; Figure 2). The biofilm application increased nitrogenase activity ca. 37-fold, compared with sterilised distilled water. In the three treatments, soil nitrogenase activity was proportional to plant species richness, possibly because nitrogen fixation is generally supported by root exudates of plants. The biofilm initially had two diazotrophs, but seven diazotrophs were isolated from the biofilm treated soil in comparison to the two diazotrophs, each isolated from the nutrient solution and sterilised distilled water added pots. This is attributed to breaking the dormancy of microbial seed bank in the soil from the biofilm exudates (Seneviratne \& Kulasooriya, 2013). This leads to an increase in diazotrophic soil bacteria, which

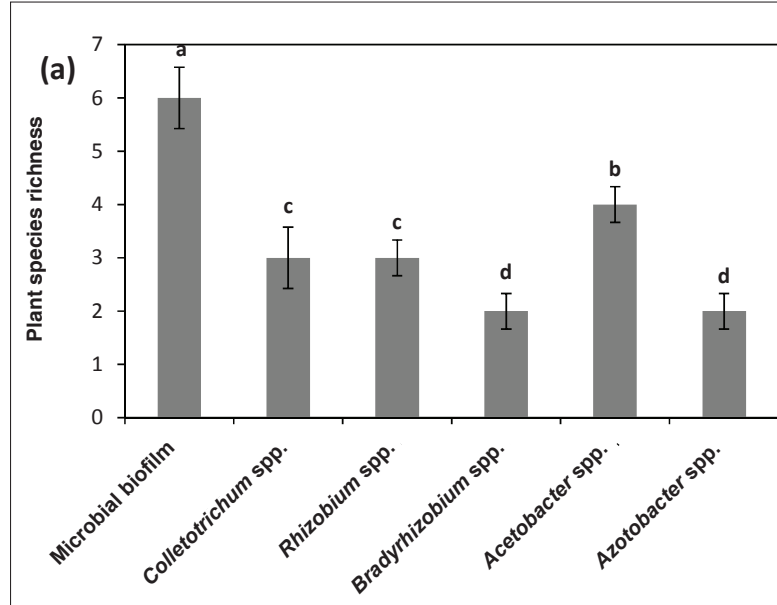

(b)

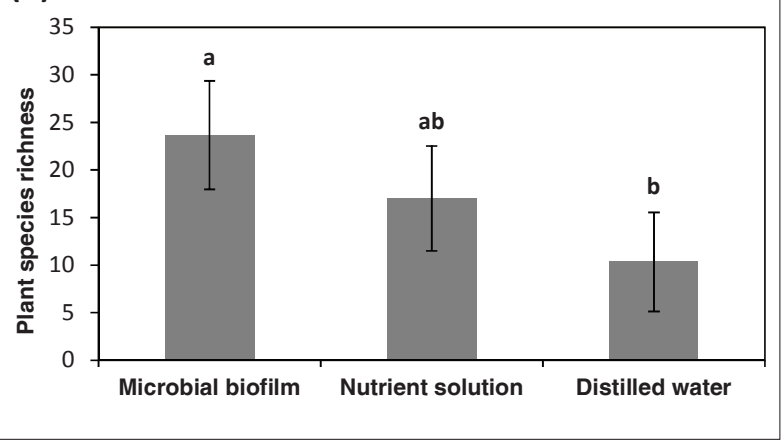

Figure 1: (a) Plant species richness in microbial biofilm, fungal monoculture (Colletotrichum spp.) and bacterial monoculture (Rhizobium spp., Bradyrhizobium spp., Acetobacter spp. and Azotobacter spp.) treated soil pots after one month of treatment; (b) plant species richness in microbial biofilm treated, nutrient solution treated and distilled water added soil pots after one month of treatment. Different letters on the columns show significant differences at $5 \%$ probability level, whereas the columns with the same letter are not significantly different at the same probability level. Vertical bars on the columns show standard errors. 
plays a key role in the growth and persistence of effective microbial communities by supplying nitrogen through biological nitrogen fixation (Seneviratne et al., 2011). This is evident from the significant positive correlation between the biomass increase of the soil microbial communities and nitrogenase activity (Zarea et al., 2009). It is reported that adverse micro-environmental factors in degraded soils such as instability and water stress constrain the growth of nitrogen fixing microorganisms (Yeager et al., 2004), because the soils cannot provide the microbial growth requirements. Interestingly, inoculation of depleted soils with developed fungal surface-attached bacterial biofilms has been shown to supply the microbial growth requirements and refresh the hampered microbial activities with overall soil fertility improvement (Seneviratne et al., 2011).
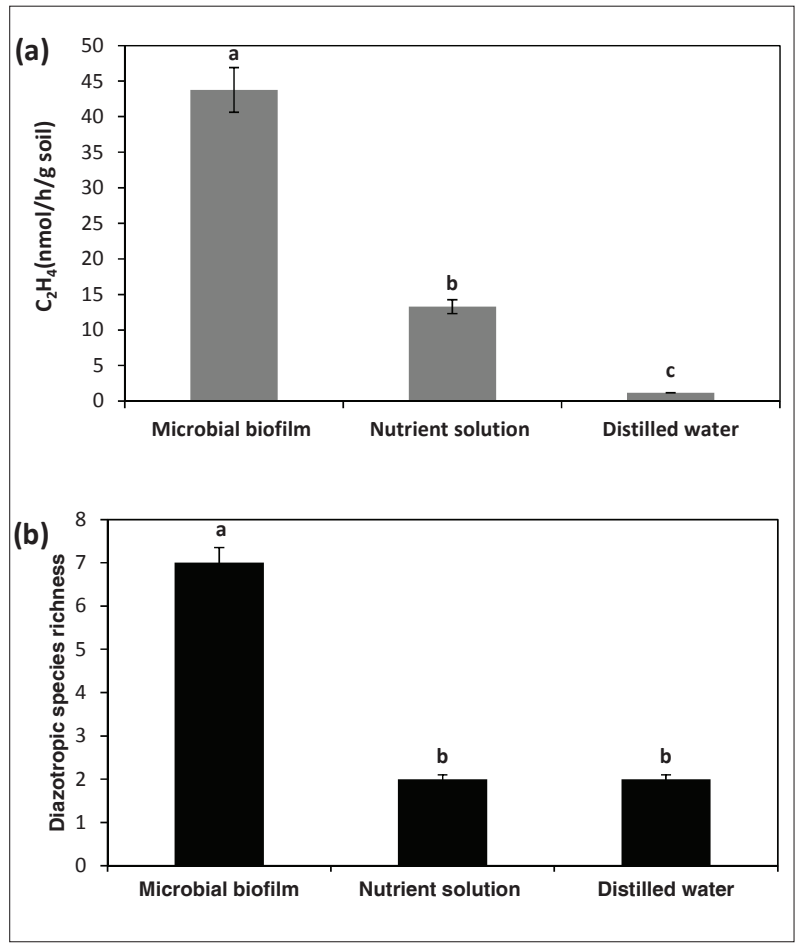

Figure 2: (a) Nitrogenase activity of microbial biofilm, nutrient solution and distilled water added soil pots as evaluated by acetylene reduction assay (ARA); (b) number of diazotrophic species in microbial biofilm, nutrient solution and distilled water added soil pots. Different letters on the columns show significant differences at $5 \%$ probability level, whereas the columns with the same letters are not significantly different at the same probability level. Vertical bars on the columns show standard errors.

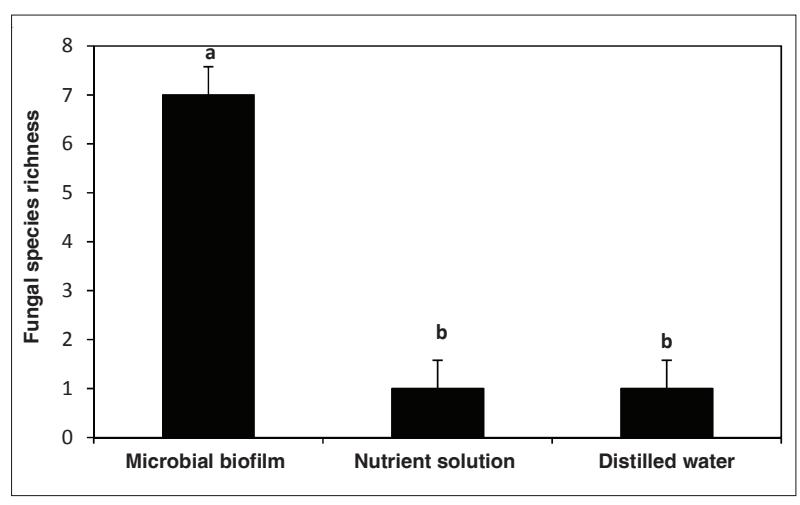

Figure 3: Fungal species richness of different treatments on potato dextrose agar plates. Different letters on the columns show significant differences at $5 \%$ probability level, whereas the columns with the same letters are not significantly different at the same probability level. Vertical bars on the columns show standard errors.

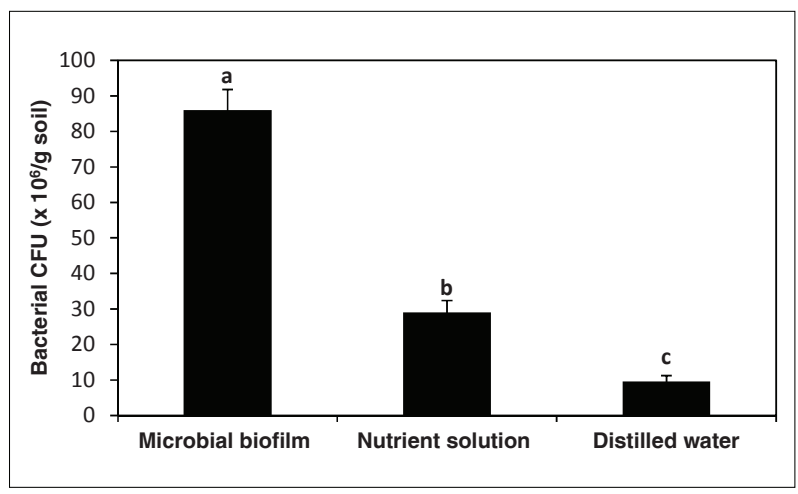

Figure 4: Bacterial colony forming units (CFU) count of different treatments on nutrient agar plates. Different letters in each measuring time show significant differences at $5 \%$ probability level. Vertical bars show standard errors.

The biofilm treated soil showed a significantly higher fungal species richness and bacterial density than the soil in the other two treatments (Figures 3 and 4), mainly due to the action of biofilm exudates as mentioned above. Although it was not significant ( $p>0.05)$, there was an increasing trend of unicellular and multicellular microfaunal counts with the biofilm treatment (data not shown). It is generally reported that bacterial and fungal interactions in the fungal-bacterial consortia establish metabolic cooperation between them (Frey-Klett et al., 2011), leading to increased production and release of environmentally important and diverse compounds 
(Seneviratne \& Kulasooriya, 2013), functions of some of which are even not yet known.
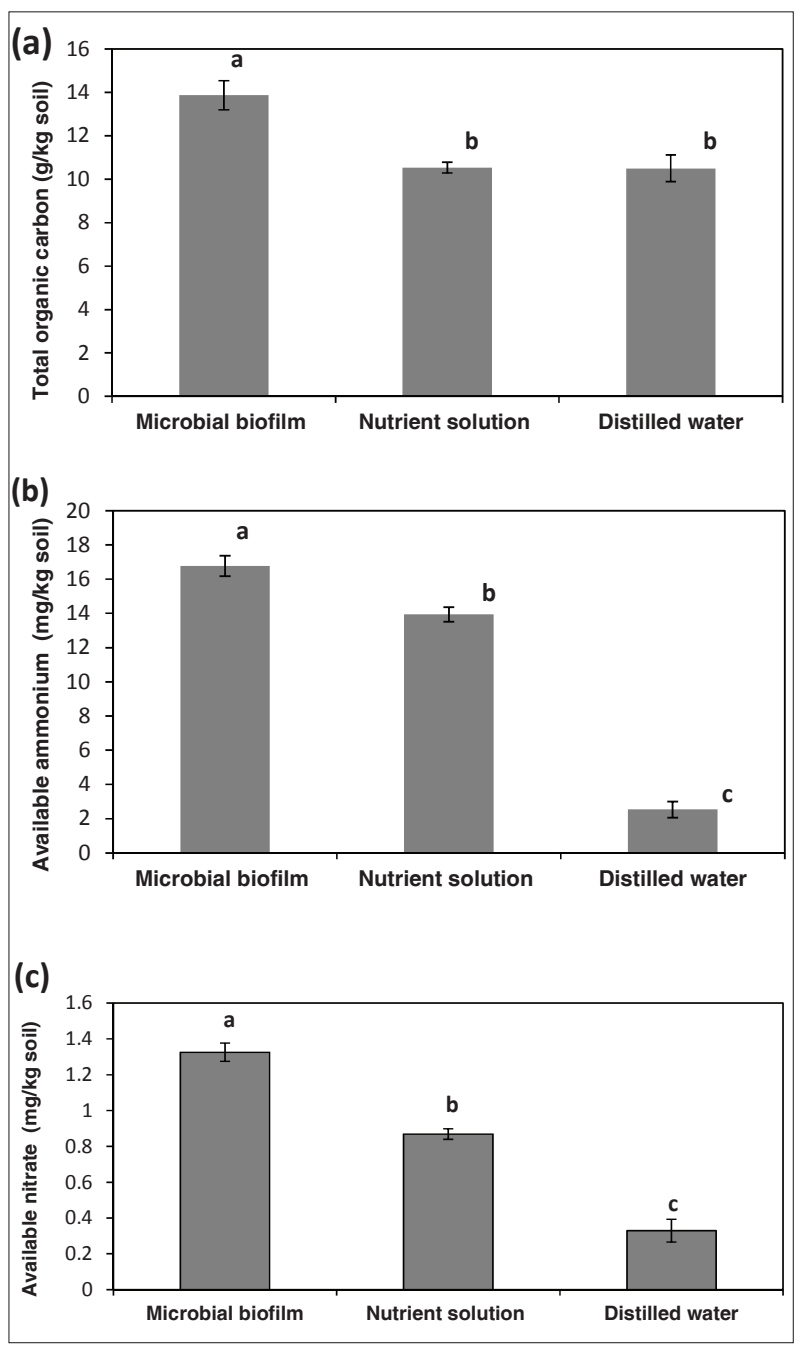

Figure 5: Changes in (a) total organic carbon; (b) available ammonium and (c) available nitrate in microbial biofilm, nutrient solution and distilled water added soil pots. Different letters on the columns show significant differences at $5 \%$ probability level, whereas the columns with same letters are not significantly different at the same probability level. Vertical bars on the columns show standard errors.

Soil organic $\mathrm{C}$, available $\mathrm{NO}_{3}{ }^{-}$and $\mathrm{NH}_{4}^{+}$were significantly higher in the biofilm treated soil than the soil in other two treatments (Figure 5). Soil available $\mathrm{NO}_{3}^{-}$increased by ca. $300 \%(\mathrm{p}<0.05)$ and $\mathrm{NH}_{4}^{+}$by ca. $560 \%(\mathrm{p}<0.05)$. This is attributable to revived microbial functioning with the application of biofilms, which leads to elevated nutrient flow in the soil (Sparling, 1997). Soil organic C increased significantly by ca. $30 \%(p<0.05)$ with the use of the biofilm. Generally, increased storage of root exudate $\mathrm{C}$ in the rhizosphere by the fungal counterparts of the increased biodiversity with the biofilm application leads to soil C build up (Seneviratne et al., 2009).

In natural ecosystems, there are interactive controls between biodiversity (species variability in particular) and functionality (Nadrowski et al., 2010; Isbell et al., 2011). These interactive controls determine the structure of the ecosystems (Chapin et al., 1996). It has been reported that the functional stability of the ecosystems is strongly influenced by microbial communities (Wittebolle et al., 2009). Hence, strengthening the microbial community structure via manipulated inoculation can increase the diversity of the interactive, biotic counterparts in any ecosystem, and the revived microbial community structure will restore the interrupted ecological balance and pathways in the ecosystem.

\section{CONCLUSION}

It is clear from the present study that inoculation of the developed microbial biofilms positively influence the bacterial, fungal and plant species richness and quality parameters of the soil. This will lead to rehabilitate the biodiversity niches especially in deteriorated agroecosystems. Thus, the fungal surface-attached bacterial biofilms developed in the present study may have the potential to be used as a novel biotechnological tool to mitigate biodiversity loss in agroecosystems and perhaps in natural ecosystems.

\section{Acknowledgement}

Ms K. Karunaratne, Mr A. Pathirana and Mr M.A. Lal of the Microbial Biotechnology Unit, National Institute of Fundamental Studies, Hantana Road, Kandy, Sri Lanka helped in the laboratory preparations and analyses.

\section{REFERENCES}

1. Anderson J.M. \& Ingram J.S.I. (eds.) (1993). Tropical Soil Biology and Fertility: A Handbook of Methods, $2^{\text {nd }}$ edition, pp. 221. CAB International, Willingford, UK.

2. Cataldo D.A., Haroon M., Schreder L.E. \& Youngs V.L. (1975). Rapid colorimetric determination of nitrate in plant tissue by nitration of salicylic acid. Communications in Soil Science and Plant Analysis 6(1): $71-80$.

DOI: https://doi.org/10.1080/00103627509366547

3. Chapin F.S., Torn M.S. \& Tateno M. (1996). Principles of ecosystem sustainability. The American Naturalist 148(6): $1016-1037$.

DOI: https://doi.org/10.1086/285969

4. Coleman D.C., Blair J.M., Elliott E.T. \& Wall D.H. (1999). 
Soil invertebrates. Standard Soil Methods for Long-term Ecological Research (eds. G.P. Robertson, D.C. Coleman, C.S. Bledsoe \& P. Sollins), pp. 349-377. Oxford University Press, Oxford, UK.

5. Frey-Klett P., Burlinson P., Deveau A., Barret M., Tarkka M. \& Sarniguet A. (2011). Bacterial-fungal interactions: hyphens between agricultural, clinical, environmental and food microbiologists. Microbiology and Molecular Biology Reviews 75(4): $583-609$.

DOI: https://doi.org/10.1128/MMBR.00020-11

6. Goenadi D.H. \& Santi L.P. (2009). Introduction of microbial inoculants to improve functional relationship between above and below ground biodiversity. Menara Perkebunan 77(1): 58 - 67.

7. Hadgu K.M., Rossing W.A.H., Kooistra L. \& van Bruggen A.H.C. (2009). Spatial variation in biodiversity, soil degradation and productivity in agricultural landscapes in the highlands of Tigray, northern Ethiopia. Food Security 1(1): $83-97$.

DOI: https://doi.org/10.1007/s12571-008-0008-5

8. Isbell F., Calcagno V. \& Hector A. (2011). High plant diversity is needed to maintain ecosystem services. Nature 477: $199-202$.

DOI: https://doi.org/10.1038/nature10282

9. Jackson L., Bawa K., Pascual U. \& Perrings C. (2005). Agro-biodiversity: a new science agenda for biodiversity in support of sustainable agroecosystems. DIVERSITAS Report No. 4, pp. 40. Available at http://www.diversitasinternational.org/resources/publications/reports-1/ agroBIODIVERSITY\%20SP.pdf, Accessed 15 May 2014.

10. Kleijn D., Rundlo M., Scheper J., Henrik G.S. \& Tscharntke T. (2011). Does conservation on farmland contribute to halting the biodiversity decline? Trends in Ecology and Evolution 26(9): $474-481$.

DOI: https://doi.org/10.1016/j.tree.2011.05.009

11. Koomnok C., Teaumroong N., Rerkasemc B. \& Lumyonga S. (2007). Diazotroph endophytic bacteria in cultivated and wild rice in Thailand. ScienceAsia 33: $429-435$.

12. Macel G.M. et al. (13 authors) (2010). Biodiversity targets after 2010. Current Opinion in Environmental Sustainability 2(1-2): $3-8$.

13. Mangan S.A., Schnitzer S.A., Herre E.A., Mack K.M.L., Valencia M.C., Sanchez E.I. \& Bever D.J. (2010). Negative plant-soil feedback predicts tree-species relative abundance in a tropical forest. Nature 466: $752-755$.

DOI: https://doi.org/10.1038/nature09273

14. Nadrowski K., Wirth C. \& Scherer-Lorenzen M. (2010). Is forest diversity driving ecosystem function and service? Current Opinion in Environmental Sustainability 2(1 - 2): $75-79$.

15. Phalan B., Onial M., Balmford A. \& Green R.E. (2011). Reconciling food production and biodiversity conservation: land sharing and land sparing compared. Science 333: $1289-1291$.

DOI: https://doi.org/10.1126/science.1208742

16. SAS (1998). SAS/STAT User's guide, Release 6.0. SAS Institute Inc., Cary, NC.
17. Seneviratne G. (2012). Are we wrong in conventional approach of biocontrol? Current Science 103: 1387 - 1388.

18. Seneviratne G., Jayasekara A.P.D.A., De Silva M.S.D.L. \& Abeysekera U.P. (2011). Developed microbial biofilms can restore deteriorated conventional agricultural soils. Soil Biology and Biochemistry 43(5): 1059 - 1062.

DOI: https://doi.org/10.1016/j.soilbio.2011.01.026

19. Seneviratne G. \& Kulasooriya S.A. (2013). Reinstating soil microbial diversity in agroecosystems: the need of the hour for sustainability and health. Agriculture, Ecosystems and Environment 164: $181-182$.

DOI: https://doi.org/10.1016/j.agee.2012.10.002

20. Seneviratne G., Thilakaratne R.M.M.S., Jayasekara A.P.D.A., Seneviratne K.A.C.N., Padmathilake K.R.E. \& De Silva M.S.D.L. (2009). Developing beneficial microbial biofilms on roots of non-legumes: a novel biofertilizing technique. Microbial Strategies for Crop Improvement (eds. M.S. Khan, A. Zaidi \& J. Musarrat), pp. 51 - 52. Spinger, Heidelberg, Berlin, Germany.

DOI: https://doi.org/10.1007/978-3-642-01979-1_3

21. Seneviratne G., Zavahir J.S., Bandara W.M.M.S. \& Weerasekara M.L.M.A.W. (2008). Fungal-bacterial biofilms: their development for novel biotechnological applications. World Journal of Microbiology and Biotechnology 24(6): 739 - 743.

DOI: https://doi.org/10.1007/s11274-007-9539-8

22. Sparling G.P. (1997). Soil microbial biomass, activity and nutrient cycling as indicators of soil health. Biological Indicators of Soil Health (eds. C. Pankhurst, B.M. Doube \& V.V.S.R. Gupta), pp. 97 - 119. CAB International, Wallingford, UK.

23. Swarnalakshmi K., Prasanna R., Kumar A., Pattnaik S., Chakravarty K., Shivay Y.S., Singh R. \& Saxena A.K. (2013). Evaluating the influence of novel cyanobacterial biofilmed biofertilizers on soil fertility and plant nutrition in wheat. European Journal of Soil Biology 55: 107 - 116. DOI: https://doi.org/10.1016/j.ejsobi.2012.12.008

24. van der Heijden M.G.A., Bakker R., Verwaal J., Scheublin T.R., Rutten M., van Logtestijn R. \& Staehelin C. (2006). Symbiotic bacteria as a determinant of plant community structure and plant productivity in dune grassland. FEMS Microbiology Ecolology 56(2): 178 - 187. DOI: https://doi.org/10.1111/j.1574-6941.2006.00086.x

25. Watson R.T., Heywood V.H., Baste I., Dias B., Gámez R., Janetos T., Reid W. \& Ruark G. (1996). Global Biodiversity Assessment: Summary for Policy-Makers, $1^{\text {st }}$ edition, pp. 56. Cambridge University Press, Cambridge, UK.

26. Wittebolle L., Marzorati M., Clement L., Balloi A., Daffonchio D., Heylen K., De Vos P., Verstraete W. \& Boon N. (2009). Initial community evenness favours functionality under selective stress. Nature 458: 623 - 626 . DOI: https://doi.org/10.1038/nature07840

27. Yeager C.M., Kornosky J.L., Housman D.C., Grote E.E. \& Belnap J.C.R.K. (2004). Diazotrophic community structure and function in two successional stages of biological soil crusts from the Colorado plateau and Chihuahuan desert. Applied and Environmental Microbiology 70(2): 973 - 983. DOI: https://doi.org/10.1128/AEM.70.2.973-983.2004 
28. Zak D.R., Holmes W.E., White D.C., Peacock A.D. \& Tilman D. (2003). Plant diversity, soil microbial communities, and ecosystem function: are there any links? Ecology 84(8): 2042 - 2050.

DOI: https://doi.org/10.1890/02-0433

29. Zarea M.J., Ghalavand A., Goltapeh M.E. \& Rejali F. (2009). Role of clover species and AM Fungi (Glomus mosseae) on forage yield, nutrients uptake, nitrogenase activity and soil microbial biomass. Journal of Agricultural Technology 5(2): $337-347$.

30. Zuberer D.A. \& Silver W.S. (1978). Biological dinitrogen fixation (acetylene reduction) associated with Florida mangroves. Applied and Environmental Microbiology 35(3): $567-575$. 